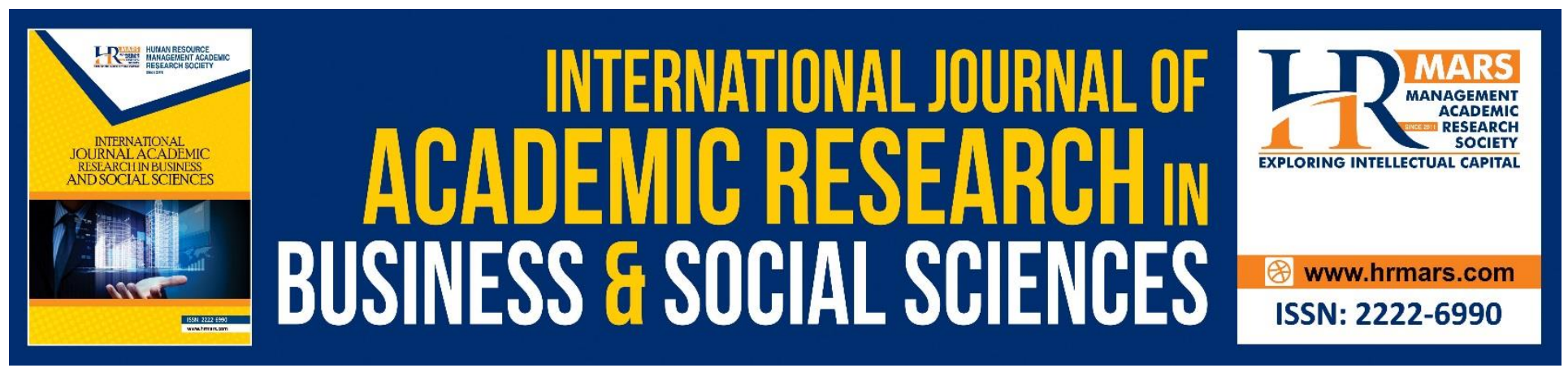

\title{
The Pilot Study on the Perception of the Society towards the Federal Constitution from the Aspect of Racial Unity
}

Fairojibanu, Nazri Muslim, Abdul Latif Samian

To Link this Article: http://dx.doi.org/10.6007/IJARBSS/v8-i11/4899

DOI: $10.6007 /$ IJARBSS/v8-i11/4899

Received: 16 Oct 2018, Revised: 02 Nov 2018, Accepted: 16 Nov 2018

Published Online: 26 Nov 2018

In-Text Citation: (Fairojibanu, Muslim, \& Samian, 2018)

To Cite this Article: Fairojibanu, Muslim, N., \& Samian, A. L. (2018). The Pilot Study on the Perception of the Society towards the Federal Constitution from the Aspect of Racial Unity. International Journal of Academic Research in Business and Social Sciences, 8(11), 273-284.

Copyright: (c) 2018 The Author(s)

Published by Human Resource Management Academic Research Society (www.hrmars.com)

This article is published under the Creative Commons Attribution (CC BY 4.0) license. Anyone may reproduce, distribute, translate and create derivative works of this article (for both commercial and non-commercial purposes), subject to full attribution to the original publication and authors. The full terms of this license may be seen

at: http://creativecommons.org/licences/by/4.0/legalcode

Vol. 8, No. 11, 2018, Pg. 273 - 284

http://hrmars.com/index.php/pages/detail/IJARBSS

JOURNAL HOMEPAGE

Full Terms \& Conditions of access and use can be found at http://hrmars.com/index.php/pages/detail/publication-ethics 


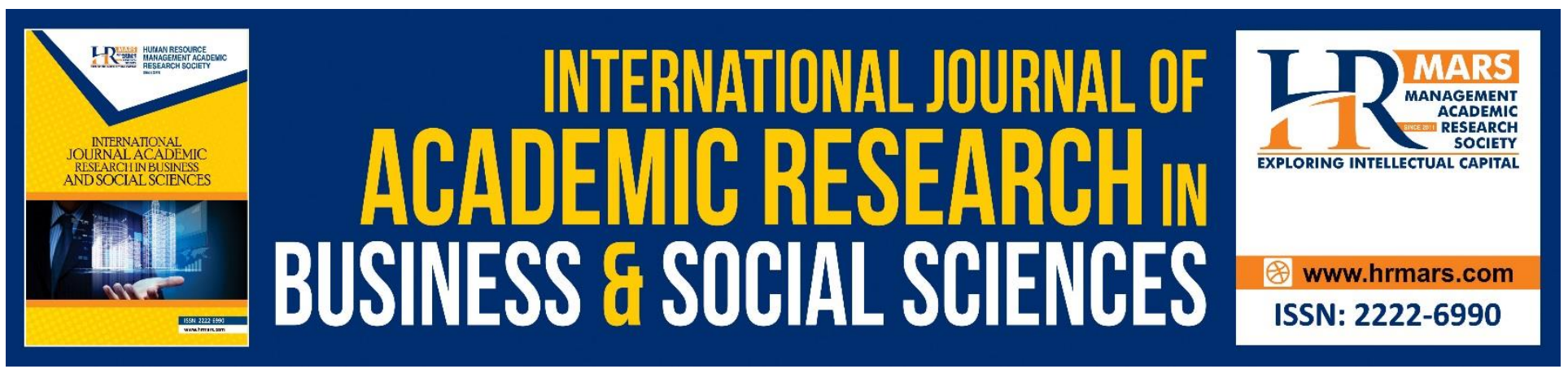

\title{
The Pilot Study on the Perception of the Society towards the Federal Constitution from the Aspect of Racial Unity
}

\author{
Fairojibanu \\ Institute of Malay World and Civilization, National University of Malaysia, Malaysia \\ Email: fairojibanu@perpaduan.gov.my \\ Nazri Muslim \\ Centre of Citra, National University of Malaysia, Malaysia \\ Email: nazrim@ukm.edu.my \\ Abdul Latif Samian \\ Institute of Malay World and Civilization, National University of Malaysia, Malaysia \\ Email: abdlatif@ukm.edu.my
}

\begin{abstract}
The constitution is the main and the highest body of law for a government. The Malaya Federal Constitution was enacted by the Reid Commission and declared on the 31 August 1957. In formulating this constitution, the Malays and the non-Malays have agreed with several agreements known as the social contract. The unity and harmony among various races in Malaya are the basis for strength of the success for the formation of the Malaya Federal Constitution. Great sacrifice and efforts from various races with the aim to demand for independence have been invaluable and they need to be preserved in ensuring that our country continues to prosper following the racial unity that has been established. However, the issues surrounding the allocation for Malays that has been collectively agreed still exist and are often raised despite the 61 years of independence. The polemic about the social contract shows that the level of knowledge and the understanding of Malaysians is still low and less understood, unlike the time when the agreement about the social contract in formulating the Malaya Federal Constitution was established. Thus, this article will discuss in detail the history of the Formulation of the Federal Constitution involving three main races namely Malaya, Chinese and Indiann from the perspective of the library study and the pilot study from the perspective of the National unity.
\end{abstract}

Keywords: Federal Constitution, Social Contract, Independence, Harmony, Unity 
INTERNATIONAL JOURNAL OF ACADEMIC RESEARCH IN BUSINESS AND SOCIAL SCIENCES

Vol. 8, No. 11, Nov, 2018, E-ISSN: 2222-6990 @ 2018 HRMARS

\section{INTRODUCTION}

The Malaysia that we are living in today, comprises of various layers of the community represented by different ethnic groups, faiths, culturs and customs. The people live in harmony and they respect one another. Sikap saling memahami dan menerima perbezaan antara satu sama lain merupakan kekuatan dalam memastikan acuan perpaduan dan pembinaanbangsa Malaysia yang bersatupadu.

According to the 2010 Demographic Basic Characteristics and Population Distribution from the Malaysian Statistics Department, the total number of Malaysian population was 28.3 million, compared to 23.3 million in 2000. This is the data based on a census done in 2010 which is the fifth census conducted since Malaysia was founded in 1963. The Census Outcome in 2010 also establishes that the total number of Malaysian population was 28.3 million encompassing 91.8 percent of the citizens and 8.2 percent non-citizens. Malaysians comprise of ethnic groups of the Bumiputera (67.4\%), Chinese (24.6\%), Indian (7.3\%) and others (0.7\%). Among Malaysians, Malay has been the main ethnic group in the Peninsula which makes up 63.1 percent. Iban noted 30.3 percent from the total number of citizens in Sarawak, whereas Kadazan/Dusun recorded 24.5 percent in Sabah.

According to Abdul Rahman Embong (2009) in terms of citizenship, Malaysia practices the parliamentary democratic and monarchy system with the General election held from the independence year until now. He added that the Malaysian independence is the result of the struggle of the people of all races who firmly held on to the principles of unity, cooperation and understanding.

Although our country practices a parliamentary democratic system, it is undeniable that the dissatisfaction and issues still persist among our society. Ismail Adnan (2007) reported that when the Chinese Association Election Plea Commitee (SUQUI) in 1999 comprising of 83 demands under 17 items that wish to fulfil the rights of the Chinese. This is also among the issues that affect the harmony and automatically illustrates a misunderstanding about the Federal Constitution. Following this, the Prime Minister at the time Dato' Seri Dr. Mahathir Mohamed had informed the Dewan Rakyat that the Malaysian constitution and the social contract that serves as the mainstay for barious ethnic groups have to be abandoned if all 83 demands from the pressure group, SUQUI, were accepted by the government. According to him, if all the demands were met, Malaysia would no longer be prosperous and it would not be advanced. This is supported by Nazri (2013) who stated that issues involving the social contract and the traditional element in the Federal Constitution related to the position of Islam and the Malays will always be polemic, conflicting and controversial in the Malaysian society since the formulation of the Federal Constitution. According to Nazri (2013), the polemic of the issues in the social contract shows just how important is the element in the social contract that needs to be understood and practised by the younger generation.

In relation to this, the understanding and practice of the social contract element are very important in ensuring that there is harmony to the special position of the Malays and that the leniency in the requirements for the non-Malays do not affect the status of other races. They have their own strengths and weaknesses. This dispute between racesnshould have never happened.Nazri (2011) has outlined four aspects showing the elements of specialty of the Malays compared to other races.

Although the Malays acquired the special entitlement, as dictated in the constitution, it was not through non-Malays' asset seizure but instead from the overall economic gains; 
i. The implementation of the special rights of the Malays did not affect the economy, also the education and politics of the non-Malays, because in both the economic and education sectors, they are far better than the Malays.

ii. The special rights of the Malays are something that have been around even before the Independence and reinstated when the constitution was formulated.

iii. It was an agreement sealed through inter-ethnic discussions and negotiations.

The independence of a country requires a constitution which is a set of documents and guideline of the administration management of a country. The constitution is the main and the highest body of law in a country. In formulating it, the Malays and non-Malays have agreed to several agreements known as the social contract.

\section{THE DEFINITION OF THE CONSTITUTION}

Hashim Yeop Sani (1983) opined that the constitution is beyond any matter solely related to government affairs, frameworks of the democracy and the protection over the rights of the people. It is also a document containing basic allocations where exclusively, it reflects considerations of harmonious situations, good acceptance and understanding among the people. This indicates that the constitution is not only a law document, but also a document that is not separated from the history, development and tradition of a country, especially for Malaysia which is a pluralistic country.

According to Nazri (2014), the constitution is the source of the highest law and every individual needs to abide by the rules. According to him, there is no institution in Malaysia that can overrule the highest rank of the Federal Constitution. Nazri (2014) also stated that the social contract agreed upon in planning on the constitution is known as the Main Pillar of the Constitution because the issues of Islam, the special position of the Malays and the Malay Language often become the conflict in the society. Thus, with the use of the Constitutional Pillar, it reflects on the importance of this issue so that there will be no dispute among the various ethnic groups in Malaysia.

For a sovereigned country, the constitution serves as the highest body of law where every individual as the people must respect its nobility. The constitution plays the role as guideline to arrange or coordinate the country's administration. The constitution is also the guideline in the formation of law, be it for the government of the people.

\section{THE COOPERATION AND UNITY AMONG MALAYAN CITIZENS TOWARDS THEIR OWN GOVERNMENT}

The Malays started to show a strong sense of solidarity and affiliation when Malayan Union was set up. Malayan Union founded by the British on 1 April 1946 aimed to unite the Federated Malay States, non-Federated Malay States and Straits Settlements with Singapore remaining as a separate territory. Zainal Abidin Abdul Wahid (1979) stated that the Malayan Union constitution had granted the citizenship right to the non-Malays through the principle of jus soli which means that if one is to be born in Malaya after Malayan Union, one has the right to have his or her citizenship easily. Even Mohd. Aris (1983) had opined that in the Malayan Union constitution, the citizenship was given to anyone who regarded this country as their own. This means that the non-Malays have the same right with the Malays. This will cause the priorities of the Malays to deteriorate. In terms of the administration, Malayan Union will be led by the Governor. The Sultan will only be the advisor to the 
INTERNATIONAL JOURNAL OF ACADEMIC RESEARCH IN BUSINESS AND SOCIAL SCIENCES Vol. 8, No. 11, Nov, 2018, E-ISSN: 2222-6990 @ 2018 HRMARS

Governor and no longer become the head of the country; and the advice is not necessarily accepted by the Governor.

As a sign of protest, the Malays had boycotted the appointment of the Advisory Council and the Sultans also did not attend the sworn-in of the new Governor. This action shows that for the first time, the Malays had been united and defended their interests. Following the opposition from the Malays and the Malayan Union's plan being criticised in the British Parliament, the British realised that they had made a grave mistake.

According to Mohd. Aris (1983) on 25 July 1948, a Working Committee comprising of the government representatives of the Malay Kings and UMNO was founded. This committee agreed that the Malayan Union was to be replaced by a new constitution in the form of a Federation. Two of the suggestions are the creation of a strong government and the opportunity to have its own government. The citizenship is open to all races who regard Malaya as their homeland and their center of loyalty.

However, in December 1946 the governor of the Malayan Union appointed a consultation committee comprising of various groups of non-Malays that have a lot of influence. As the result, this Committee also made the decision to form a Federation. This Federation comprises of 9 Malay states and 2 Straits Settlements (Melaka and Penang). Through this Federation Agreement, the central government has the full power and responsibility in all matters and at the same time retain the jurisdiction of the kings in Islamic affairs and Malay customs. This shows that the sovereignty of the Malay kings and the special rights of the Malays were returned. In terms of the citizenship, the principle of jus soli was also abolished. Finally, the Federation Agreement that has become the basis of the new regulations will set up a Federation named the Federation of Malaya that was declared on 1 February 1948.

The introduction to the Federation of Malaya had created a strong collaboration between Malays and non-Malays. Khong Kim Hoong (1984) stated that the establishment of the Communities Liason Committee (CLC) in 1949 comprising of various ethnic groups had resolved some of the issues regarding the constitution, politics and economy that have come about, following the different requests made by these various groups.

According to Hasnah Hussiin (2009), a stronger cooperation between the Malays and the nonMalays persisted when British conditioned that independence would only be granted if the people of this country united and could work with one another. The demand for the independence outstretched the racial issues where it transformed a fragmented society into an affiliated one. Such a circumstance also drove them to side-step the narrow views of racism and work towards demanding for independence from the colonial power. According to Ho Hui Ling (2007), when Lennox Boyd, the National Secretary for the new state of dependency paid a visit to Kuala Lumpur at the end of August in 1955, Tunku Abdul Rahman had started a discussion about their own administration and independence for Malaya. Lennox Boyd had assured Tunku to hold a constitutional meeting in London in the early months of 1956 under the condition that Malay kings could also send their representatives due to the fact that from the perspective of the constitution, they were also part of any changes that were to be made.

In the effort to form a government, Reid Commission was established to formulate the constitution of Malaya. However, the Reid Commission report received protestation from various 
parties. To consolidate the proposal of the constitution, a Working Party Committee was set up to issue a White Paper. Working Party was ch aired by MacGillivar with four representatives from the Alliance and four representatives from Malay Kings. The representatives from the Alliance Party were Tunku Abdul Rahman (UMNO), Datuk Abdul Razak (UMNO). Ong Yoke Lin (MCA) and V.T Sambanthan (MIC), whereas the spokepersons for the Kings were Mustapha Albakri (Keeper of the Ruler's Seal), Shamsudin Nain, Tunku Ismail Tunku Yahya and Neil Lawson. Other members were State Head of Secretary, Sir David Watherson, General Attorney, T.V. A Brodie and E.O Laird as the Secretary.

Utusan Melayu (1957) dated 3 July reported that the matters amended by the Working Party towards the suggestions made by Reid Commission include the issues of citizenship, the special rights of the Malay and the national language. Working Party had made the decision that the name of this country was to be known as Persekutuan Malaya or in English, the Federation of Malaya. The framework of Reid Commision did not mention the name Persekutuan Malaya but only mentioned the English name which is the Federation of Malaya.

Joseph M. Fernando (2002 reported that :

i. $\quad$ For matters regarding the special rights of the Malay, Working Party had handed this over to the Yang di Pertuan Agong and it was his discretion to determine when the special rights of the Malays should be revised. This had been decided by the members of the Working Party although initially it was not agreed upon by MCA regarding the duration of revision after 15 years.

ii. $\quad$ For matters about citizenship, Working Party had agreed that everyone who was a citizenship before the Independence should have their rights remained as citizens and all born in the Federation of Malaya after Independence Day must become citizens according to the law. Jus soli will only be granted to children born after 31 August 1957. This was relieving for the Malays because this means that the non-Malays can only become citizens after 21 years of independence.

iii. Islam was endorsed as the religion of the federation and other religions are also free to be practised.

iv. There is no amendment for the allocation for the Malay Language according to Reid Commission that stresses on the use of English after ten years of independence.

Joseph M. Fernando (2002) also stated that there are various reactions in the White Paper discussion. One includes from S.M. Zainal Abidin who asserted that the racial sentiment must be abolished to ensure that the country stays in prosperity. Meanwhile for the Serani represented by J.Sili they welcomed the constitution and stated that there was a new constitution and 31 August is the Independent Day which is a historic date for Malaya. He added that S.N King, the representative for rubber Production Council had applauded the proposal as it was arranged for the benefit of all and not one party only. Meanwhile J.Liew stated that any shortcoming and weakness in the constitution can be revised based on opinions or views.

From there, on 9 July reported that the White Paper Proposal published on the 3 July 1957 was fully accepted by the General Committee of MCA. Tan Siew Sin who was the Head of Information for MCA stated that there was no more obstacle for the Malay Federation to obtain independence on the 31 August 1957 and this new constitution will become fundamental to Malaya administration. 
It is clear that the issues of citizenship, special rights and national language had created dissatisfaction in the Federal Constitution. This is because Malaya is occupied by people of various races. According to Nazri (2012) when formulating the constitution, both Malays and non-Malays had agreed on several issues whereby the Malays were granted lenient citizenship rights based on the jus soli principle, while the allocation for Malays in a constitution is Islam as the federal religion, Malay Language as the national language and the special position of the Malays and the position of Malay Kings and Sultans as the element of tradition in the constitution.

The unity and common interests, also the sensitivity of all races from all aspects must be considered in ensuring that the national constitution becomes the mainstay of the national administration. Although the White Paper has changed some parts of the suggestions and the proposals raised by the commissioner, it did not revoke the report. Here, the Federal Constitution of Malaysia was formulated resulting from the collective agreement that has been reached between the Malays, Chinese and Indians as Malaysians. Federal Constitution is not only a legislative document but also a social contract and peace treaty.

\section{RESEARCH METHODOLOGY}

The finding of the pilot study was carried out in the Klang Valley in 2016 involving 50 respondents or the population comprising of the Malays, Chinese and Indians. The ratio of the study involves 25 Malays, 15 Chinese and 10 Indians. The study carried out entitled "The Malays According to the Constitution in the Context of Ethnic Relations in Malaysia".

\section{DATA ANALYSIS AND DISCUSSION}

Referring to Timetable 1 with regard to the level of knowledge about the social contract, it shows that the percentage of Malays who know is 36 percent whereas those with less knowledge is 60 percent. The Chinese claimed to know more, with regard to the social contract which is 86.7 percent compared to less knowledgeable which is 13.3 percent. The Indianns have the same level of knowledge between knowing and not really knowing. The finding explains that relatively, the Chinese have the higher level of knowledge about the social contract compared to the knowledge of the Malay counterparts, to ensure that their rights are preserved.

Table 1: The social contract refers to the compromise between the Malays and the non-Malays

\begin{tabular}{|c|c|c|c|}
\hline Ethnic & Dont know & Not really know & Know \\
\hline Malay & $1(4.0 \%)$ & $15(60.0 \%)$ & $9(36.0 \%)$ \\
\hline Chinese & $0(0.0 \%)$ & $2(13.3 \%)$ & $13(86.7 \%)$ \\
\hline Indian & $0(0.0 \%)$ & $5(50.0 \%)$ & $5(50.0 \%)$ \\
\hline
\end{tabular}

Table 2 shows the percentage of the knowledge about the special position of the Malays which is one of the elements that have existed before the Federal Constitution was formulated in 1957. In terms of the level of knowledge, the Chinese have high level which is $66.7 \%$ compared to less knowledgeable, 26.7\%. Meanwhile, for the Malays they have 36 percent compared to less 
INTERNATIONAL JOURNAL OF ACADEMIC RESEARCH IN BUSINESS AND SOCIAL SCIENCES Vol. 8, No. 11, Nov, 2018, E-ISSN: 2222-6990 @ 2018 HRMARS

knowledgeable with a higher percentage of 60 percent. There is a slight difference betwen the Indians' level of knowledge between knowing and not really knowing, which is 40 percent (knowing) and 50 percent (not really knowing) and 10 percent (not knowing anything at all).

The data outcome shows that the percentage of the level of the Chinese is higher with regard to the social contract and the special position of the Malays compared to the latter with the percentage of of less knowledgeable higher for both aspects. This reflects that the Malays are in their 'comfort zone' and they do not have the interest to know in further detail about the special position of the Malays. This causes them to experience weakness in defending their position and rights should there be any issues about this raised by other races.

Table 2: The special position of the Malays, is an element that has existed before the Constitution was enacted in 1957

\begin{tabular}{|c|c|c|c|}
\hline Ethnic & $\begin{array}{c}\text { Dont } \\
\text { understand }\end{array}$ & $\begin{array}{l}\text { Do not really } \\
\text { understand }\end{array}$ & Understand \\
\hline Malay & $1(4.0 \%)$ & $15(60.0 \%)$ & $9(36.0 \%)$ \\
\hline Chinese & $1(6.7 \%)$ & $4(26.7 \%)$ & $10(66.7 \%)$ \\
\hline Indian & $1(10.0 \%)$ & $5(50.0 \%)$ & $4(40.0 \%)$ \\
\hline
\end{tabular}

Table 3 concerns with the understanding about the position of the Federal Constitution ; where it is found that 36 percent of the Malays understand while 64 percent do not really understand. The Chinese have the higher level of understanding where 53.3 percent understand and 46.7 percent do not really understand. The Indians have the same level of understanding where 50 percent respectively for understand and not really understanding. Data shows that the percentage of understanding of the Chinese is higher than their percentage of not really understanding. Meanwhile, for the Malays, their percentage of lacking the understanding is higher than the percentage of understanding. The Chinese spend more time to study things in the Federal Constitution. They are very sensitive and also very passionate in increasing their knowledge in this issue to ensure that they can always be safe and secure.

Table 3: Federal Constitution is the highest body of law in Malaysia and no one can overrule the constitution

\begin{tabular}{|c|c|c|c|}
\hline Ethnic & $\begin{array}{c}\text { Dont } \\
\text { understand }\end{array}$ & $\begin{array}{l}\text { Do not really } \\
\text { understand }\end{array}$ & Understand \\
\hline Malay & $0(0.0 \%)$ & $16(64.0 \%)$ & $9(36.0 \%)$ \\
\hline Chinese & $0(0.0 \%)$ & $7(46.7 \%)$ & $8(53.3 \%)$ \\
\hline Indian & $0(0.0 \%)$ & $5(50.0 \%)$ & $5(50.0 \%)$ \\
\hline
\end{tabular}

In terms of the understanding on issues in the social contract such as in Table 4 the lack of understanding of the Malays is higher than the level of understanding respectively 48 percent and 40 percent. The Chinese show higher level of understanding compared to the lack of understanding, 
INTERNATIONAL JOURNAL OF ACADEMIC RESEARCH IN BUSINESS AND SOCIAL SCIENCES Vol. 8, No. 11, Nov, 2018, E-ISSN: 2222-6990 @ 2018 HRMARS

which is 46.7 percent and 40 percent. The same goes with the Indians where the level of understanding is higher, which is 60 percent compared to their lack of understanding, 20 percent. For the total lack of understanding, the Malays show 12 percent, the Chinese 13 percent, and the Indians the highest which is 20 percent. The highest level of understanding among the Indians show that they comprehend the spirit of tolerance among the races that needs to be practised in our country of various races. The highest level of the lack of understanding among the Chinese clearly supports the issues in life raised by the Chinese towards other races, especially the Malays. This lack of understanding is the reason for the dispute and misunderstanding on sensitive issues surrounding a particualr race.

Table 4: The social contract refers to the spirit of tolerance between the Malays and the non-Malays.

\begin{tabular}{|c|c|c|c|}
\hline Ethnic & $\begin{array}{c}\text { Dont } \\
\text { understand }\end{array}$ & $\begin{array}{l}\text { Do not really } \\
\text { understand }\end{array}$ & Understand \\
\hline Malay & $3(12.0 \%)$ & $12(48.0 \%)$ & $10(40.0 \%)$ \\
\hline Chinese & $2(13.3 \%)$ & $6(40.0 \%)$ & $7(46.7 \%)$ \\
\hline Indian & $2(20.0 \%)$ & $2(20.0 \%)$ & $6(60.0 \%)$ \\
\hline
\end{tabular}

In terms of the percentage of understanding of all three races with regard to the special position of the Malays that has long existed before the Federal Constitution was enacted as in Table 5 , it shows that the percentage of Malays who understand is 40 percent, who do not really understand 48 percent and 12 percent who totally do not understand. 40 percent of the Chinese understand and 60 percent do not really understand. The Indians show the highest percentage of the lack of understanding, which is 70 percent lack of understanding and 30 percent understand. The data explains that the percentage of the lack of understanding dominates the percentage of the understanding for all three races. The Indians need to increase their knowledge in relation to this although they are the minority in our country. They take this issue lightly and do not try to make sure that they understand the situation. They even feel that they are in a comfort zone causing them to not take any role in understanding this issue.

Table 5: The understanding on the special position of the Malays has existed hundred years before the constitution was enacted and the allocation reincluded when the Federal Constitution in 1957 was enacted.

\begin{tabular}{|c|c|c|c|}
\hline Ethnic & $\begin{array}{c}\text { Dont } \\
\text { understand }\end{array}$ & $\begin{array}{l}\text { Do not really } \\
\text { understand }\end{array}$ & Understand \\
\hline Malay & $3(12.0 \%)$ & $12(48.0 \%)$ & $10(40.0 \%)$ \\
\hline Chinese & $0(0.0 \%)$ & $9(60.0 \%)$ & $6(40.0 \%)$ \\
\hline Indian & $0(0.0 \%)$ & $7(70.0 \%)$ & $3(30.0 \%)$ \\
\hline
\end{tabular}

Table 6 shows the percentage of acceptance of all three races towards issues in the social contract. The study data shows that 56 percent of the Malays agreed to this, 36 percent did not agree and 8 percent diagreed. The Chinese show that 66.7 percent agreed and 33.3 percent did not 
INTERNATIONAL JOURNAL OF ACADEMIC RESEARCH IN BUSINESS AND SOCIAL SCIENCES Vol. 8, No. 11, Nov, 2018, E-ISSN: 2222-6990 @ 2018 HRMARS

really agree. Next, 60 percent of Indians agreed, 30 percent did not really agree and 10 percent disagreed. Data explained that the percentage of acceptance and agreement towards issues in the social contract dominates the level of disagreement and less of an agreement for all three races. All three races relatively agreed and complied with the issues stated in the social contract. The high rate of percentage of agreement from the races clearly depicts the harmony and prosperity that we have reaped and benefited today.

Table 6: The level of acceptance towards the social contract referring to the spirit of tolerance between the Malays and non-Malays

\begin{tabular}{|c|c|c|c|}
\hline Ethnic & Disagree & Less agree & Agree \\
\hline Malay & $2(8.0 \%)$ & $9(36.0 \%)$ & $14(56.0 \%)$ \\
\hline Chinese & $0(0.0 \%)$ & $5(33.3 \%)$ & $10(66.7 \%)$ \\
\hline Indian & $1(10.0 \%)$ & $3(30.0 \%)$ & $6(60.0 \%)$ \\
\hline
\end{tabular}

In terms of the percentage of acceptance of the special position of the Malays that has existed before the enactment of the Federal Constitution, this is reflected in Table 7. Data shows the percentage of the Malays who agreed to be 56 percent, 40 percent not really agreeing to it and 4 percent disagreed. For the Chinese, 80 percent agreed, 6.7 percent did not really agree and 13.3 percent disagreed. For the Indians, 60 percent agreed whereas 20 percent respectively less agreeing and disagreeing to the conditions. Clearly, it shows that all three races had a higher percentage rate towards the agreement indicator compared to the other two indicators. The high rate of percentage for the three races also shows their acceptance in endorsing the Malays' special position. They also realised that the Malays are the original residents of Malaya and they need to respect the issue. All three races were also clear about the agreement that was sealed which is the requirement of the indepence of Malaya.

Table 7: The level of acceptance towards the special position of the Malays, an element that has existed before the enactment of the Constitution in 1957

\begin{tabular}{|c|c|c|c|}
\hline Ethnic & Disagree & Less agree & Agree \\
\hline Malay & $1(4.0 \%)$ & $10(40.0 \%)$ & $14(56.0 \%)$ \\
\hline Chinese & $2(13.3 \%)$ & $1(6.7 \%)$ & $12(80.0 \%)$ \\
\hline Indian & $2(20.0 \%)$ & $2(20.0 \%)$ & $6(60.0 \%)$ \\
\hline
\end{tabular}

Table 8 shows the data of the constitutional spirit that is understood and grasped by fellow Malaysians. The data explain that 60 percent of Malays agreed and $40 \%$ did not really agree. Meanwhile, the Chinese and Indians share the same percentage where 80 percent agreed and 20 percent did not really agree. In terms of the lack of agreement, it shows that the Malays have the higher percentage of diagreement compared to the Chinese and Indians. This is because the Malays were often bombarded by various issues and other races also demanded for several things like quota in the education system. Such a demand reflects how the constitutional spirit is still not really understood by all layers of Malaysians. 
INTERNATIONAL JOURNAL OF ACADEMIC RESEARCH IN BUSINESS AND SOCIAL SCIENCES Vol. 8, No. 11, Nov, 2018, E-ISSN: 2222-6990 @ 2018 HRMARS

Table 8: The spirit of the constitution is now understood and grasped by Malaysians

\begin{tabular}{|c|c|c|c|}
\hline Ethnic & Disagree & Less agree & Agree \\
\hline Malay & $0(0.0 \%)$ & $10(40.0 \%)$ & $15(60.0 \%)$ \\
\hline Chinese & $0(0.0 \%)$ & $3(20.0 \%)$ & $12(80.0 \%)$ \\
\hline Indian & $0(0.0 \%)$ & $2(20.0 \%)$ & $8(80.0 \%)$ \\
\hline
\end{tabular}

\section{CONCLUSION}

Malaya is a unique country comprising of various backgrounds of cultures, from various races and religions. This diversity and the patterns of locations for the people in Malaya have become a great challenge that was once thought of as impossible for British to grant Malaya its own government. However, as the result of the harmony among the races, the compromise and unity in ensuring a sense of acceptance towards these differences and diversity of races had given a leap of nationalist spirit.

The Chinese and Indians who came to Malaya were well accepted by the Malays under the conditions that they collectively agreed upon in the social contract namely things related to citizenship, language, religion and the special rights of the Malays. However, from the outcome of the pilot study, it illustrates that there still exists dissatisfaction among the Chinese dan Indian towards several aspects in the Federal Constitution. The polemic of the social contract still exists among Malaysians although they have enjoyed independence for 61 years. It is found that although the Chinese have shown high understanding towards the position of the Federal Constitution as the highest law which is $53.3 \%$, the Chinese still lack the understanding where the percentage rate is relatively high compared to the Malays which is 60 percent indicating that the special position of the Malays has existed hundreds of years before the enactment of the Federal Constitution in 1957. The same goes with the sporit of unity which is also very low. Malaysians lack the understanding of the spirit of the constitution. The majority or the Malays also have high level of disagreement which is 40 percent. Although the position of the Malays is guaranteed in the constitution, there is still a percentage of high disagreement towards the spirit of constitution among Malaysians.

On this note, better inculcation and consolidation, as well as more sensitivity need to be instilled in every layer of the society. Knowledge, understanding and acceptance of various aspects in the Federal Constitution are crucial in sustaining and igniting the spirit of unity and celebrating diversity. The unity and spirit of nationalism among races are important elements in the enactment of the Federal Constitution that have become the mainstay of the management and administration of the country.

Therefore it is suggested that in order to increase the level of acceptance among Malaysian people, more effort needed to be done to make everyone have a sense of sensitivity in understanding Federal Constitution. On the other hand, National Unity and Integration Department under Prime Minister's Office also should empower its roles as a lead agency to monitor all activities organized by community at large. It is advisable for the PERPADUAN to concentrate more courses or workshops related to Malaysian Constitution for community leaders and Rukun Tetangga committee 
INTERNATIONAL JOURNAL OF ACADEMIC RESEARCH IN BUSINESS AND SOCIAL SCIENCES Vol. 8, No. 11, Nov, 2018, E-ISSN: 2222-6990 @ 2018 HRMARS

members. The reason is to ensure all community leaders from different races, religions and social backgrounds understand the important of understanding the Malaysian Constitution. Besides, they can be trained with certain methods on how to deliver the messages or share the right information in their own dialects to their members and families. Finally Federal Constitution is needed to be exposed to all Malaysian citizens.

\section{REFERENCE}

Bari, A.A. (2013). Perlembagaan Malaysia: Asas-asas dan masalah. Kuala Lumpur: Dewan Bahasa dan Pustaka

Abdul Aziz, A. R. (2010). Rukun Negara dalam Memperkukuhkan Ketahanan Negara. In Proceedings Seminar On Nasional Resiliance (SNAR 2010) "Political Management and Policies in Malaysia", 13-15 July 2010, Bayview Hotel Langkawi. Institute of Tun Dr. Mahathir Mohamad's Thoughts, Universiti Utara Malaysia, Sintok. pg.443-457.

Embong, A. R. (2009). Kepelbagaian Kaum, Perpaduan dan Pembinaan Bangsa Malaysia. In Husin, A, Ahma Farouk, A, Yean, C.S, Sivamurugun, P \& Ibrahim, A.R. Membina Bangsa Malaysia Vol 4. Integrasi Nasional. pg.196-197. Jabatan Perpaduan Negara Dan Integrasi Nasional, Kementerian Perpaduan, Kebudayaan, Keseniaan Dan Warisan Dan Pusat Pengajian Sains Kemasyarakatan Universiti Sains Malaysia.

Musa, A.S. (2006). Islam dalam Perlembagaan dan kebebasan beragama. Paperwork presented at the Seminar Pertukaran Agama dan Kesan dari Perspektif Syariah dan Perundangan. Organised by Selangor International Islamic University College. Bangi. 15 July. Bangi.

Hardig, A. (1996). Law, Government and the Constitution in Malaysia. United Kingdom: Kluwer Law International.

Fernando, J.M. (2002). The Making of the Malayan Constitution. Kuala Lumpur: JMBRAS. Sani, H.Y. (1983). Perlembagaan Kita. Kuala Lumpur: Malaysian Law Publishers Sdn. Bhd. Adnan, I. (2007). Kontrak Sosial Masyarakat Majmuk. Johor Bahru: Majlis Kebudayaan Negeri Johor.

Muslim, N. (2012). Implikasi Peruntukan Islam dan Orang Melayu dalam Federal ConstitutionTerhadap Hubungan Etnik Di Malaysia. Jurnal Kemanusiaan. Vol.19, No.2. pg 1962.

Muslim, N. (2014). Islam dan Malay dalam Perlembagaan: Tiang Seri Hubungan Etnik di Malaysia. Bangi: Universiti Kebangsaan Malaysia Publisher.

Musim, N, Musa, N.Y. dan Buang, A.H. (2011). Ethnic relations in Malaysia from an Islamic perspective. Kajian Malaysia, Vol.29, No.1. pg : 1-28.

Muslim, N, Wan Hassan, W.Z, Alias, J. and Mat, N. (2013). Mean Analysis of Student,s Levels of Knowledge, Understanding and Acceptance Towards Provisions of Islam and Malay in Federal Constitution from the Perspective of Ethnic relation in Malaysia. World Applied Sciences Journal. 22(3) : 345-358.

Abdul Wahid, Z.A. (1979). Sejarah Malaysia Sepintas Lalu. Kuala Lumpur: Dewan Bahasa dan Pustaka. 